\title{
Erratum to: Time to flowering of temperate pulses in vivo and generation turnover in vivo-in vitro of narrow-leaf lupin accelerated by low red to far-red ratio and high intensity in the far-red region
}

\author{
Janine S. Croser ${ }^{1} \cdot$ Maria Pazos-Navarro $^{1} \cdot$ Richard G. Bennett $^{1} \cdot$ Sabrina Tschirren $^{1}$ \\ Kylie Edwards $^{1} \cdot$ William Erskine $^{1} \cdot$ Robert Creasy $^{1} \cdot$ Federico M. Ribalta $^{1}$
}

Published online: 7 November 2016

(C) Springer Science+Business Media Dordrecht 2016

\section{Erratum to: Plant Cell Tiss Organ Cult \\ DOI 10.1007/s11240-016-1092-4}

In the original publication, the name of the model/manufacturer of the blue LED light used in Environments 1 and 2 is not correct. Environment 1 contained blue LED light from 18w-T8 LED tubes (model 108D18-V12; S-Tech Lighting, Australia) and Environment 2 contained a combination of blue LED light used in E1 plus far red-enriched LED light from AP67 Valoya L series (Helsinki, Finland).

The online version of the original article can be found under doi:10.1007/s11240-016-1092-4.

Federico M. Ribalta

federico.ribalta@uwa.edu.au

\footnotetext{
Centre for Plant Genetics and Breeding, The University of Western Australia, 35 Stirling Hwy, Crawley, WA 6009, Australia
} 